\title{
PLANTS USED IN THE TREATMENT OF LEISHMANIAL ULCERS DUE TO LEISHMANIA (VIANNLA) BRAZILIENSIS IN AN ENDEMICAREA OF BAHIA, BRAZIL
}

\author{
Flávio França, Ednaldo L. Lago and Philip D. Marsden
}

\begin{abstract}
This paper records the plants used in the treatment of cutaneous leishmaniasis due to Leishmania (Viannia) braziliensis ( $L(V) b$ ) among the rural population of a cocoaproducing coastal area of Babia state, Brazil. An enquiry conducted among a bundred patients identffied 49 plant species used to treat skin ulceration caused by this Leisbmania species. The principal plants used are caju-branco (Anacardium occidentale- Anacardiaceae), used by $65 \%$ of the population, folba-fogo (Clidemia hirtaMelastomataceae) 39\%, alfavaca-grossa (Plectranthus amboinicus - Lamiaceae) 33\%, mastruz (Chenopodium ambrosioides - Chenopodiaceae) 31\%, erva-de-santa-maria (Solanum americanum - Solanaceae) (25\%) and transagem (Plantago major Plantaginaceae) $2 \%$.
\end{abstract}

Key-words: Cutaneous leisbmaniasis. Leishmania (Viannia) braziliensis. Plant treatment.

Três Braços (Cravolândia, BA) and Corte de Pedra (Tancredo Neves, BA) are in an endemic area of tegumentary leishmaniasis caused by Leishmania (Viannia) braziliensis (L(V)b) ${ }^{5} 18$. The principal treatment used is the pentavalent

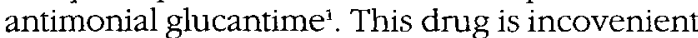
to use, since has many toxic effects and is not always available.

Reports of the use of local plants for treatment are scarce in the literature. Melo et $\mathrm{al}^{10}$ cited Cephaelis ipecacuanba (Brot.) A. Rich. (Rubiaceae) and Macedo cites Jacaranda brasiliana Piers (Bignoniaceae). Netto et al ${ }^{16}$ reported that many lesions in our study area were treated with plant products by local application. This report is an extension of this work. In view of the paucity of alternative therapy to pentavalent antimonials such an investigation is relevant.

\section{MATERIAL AND METHODS}

The study area is composed of two villages, Três Braços and Corte de Pedra, with surrounding farms. Of the 15 farms studied in Três Braços for ten years, the four which presented the highest incidence of leishmaniasis

\footnotetext{
Supported in part by NIH/Grant AI-16282

Address to: Prof. Philip D. Marsden. Núcleo de Medicina Tropical e Nutrição. Universidade de Brasília. CP: 04-671. Brasilia-DF, Brasil.

Recebido para publicação em 17/10/94.
}

were selected, namely Sobradinho, Risada, Nova Esperança II and Baixinha. From the 8 farms surrounding Corte de Pedra a further four were selected in a similar manner, namely Julião I, Julião II, Recôncavo and Pataxó I. This selection was influenced by data relating to disease incidence ${ }^{7}$ recorded in previous years.

Interviews among the population use a protocol designed after consulting reports of various previous workers ${ }^{3617}$. Data regarding a history of leishmaniasis was confirmed for each family.

If a plant was being recommended for therapy its identity and mode of application was recorded. These interviews were performed in a cumulative manner in July 1989, January 1990 and July 1990. Subjects were selected who had a history of leishmaniasis and were over 15 years of age. Only the senior author collected and analysed all data.

\section{RESULTS}

Of 100 subjects interviewed 55 used plants to treat the skin lesions. In one community (Corte de Pedra) significantly more people used plants than in the other village (Três Braços) $(p<0.15)$. Older people (over 55 years of age) tended to use significantly more $(p<0.05)$. As regards sex both men and women utilised plants but the men significantly more $(p<0.05)$. The use of plants was linked to multiple lesion occurrence $(p<0.05)$. The legs 
França F, Lago EL, Marsden PD. Plants used in the treatment of leishmanial ulcers due to Leishmania (Viannia) Braziliensis in an endemic area of Babia, Brazil. Revista da Sociedade Brasileira de Medicina Tropical 29:229-232, mai-jun, 1996.

were the most affected part (66\%). Fifty percent of patients abandoned plant therapy when gluncantime became avaiable. Fortynine common names of plants used in leishmania therapy were identified in this study. Table 1 details the six most common plants recommended by more than $20 \%$ of the 55 plant users. Table 2 details the manner of use of these species.
In both areas more than $10 \%$ of population interviewed cited the following plants: cajueiro-branco (Anacardium occidentale L.), folha-fogo (Clidemia birta L.), alfavaca-grossa (Plectrantbus amboinicus (Lour.) Spreng.), mastruz (Cbenopodium ambrosioides L.), ervade-santa-maria (Solanum americanum Mill.) and transagem (Plantago major L.). In Três Braços cocó-bravo (Xanthosoma cf. maximiliani

Table 1 - Species used by more than $20 \%$ of 55 plant users.

\begin{tabular}{llc}
\hline \multicolumn{1}{c}{ Species } & \multicolumn{1}{c}{$\begin{array}{c}\text { Common } \\
\text { name }\end{array}$} & \\
Anacardium occidentale & cajueiro branco & 35.4 \\
Clidenia bira & folha fogo & 34 \\
Plectrantrantbus amboinicus & alfavaca grossa & 30 \\
Chenopodium anbrosioides & mastruz & 17 \\
Solanum americanum & erva de santa maria & 16 \\
Plantago major & transagem & 32.7 \\
\hline
\end{tabular}

Table 2 - Manner of use of plant derivatives at site of lesion.

\begin{tabular}{|c|c|c|c|c|c|c|}
\hline \multirow[t]{2}{*}{ Manner of local use } & \multicolumn{6}{|c|}{ Species* } \\
\hline & A.O. & C. h. & P. a. & C. a. & S. a. & P. $\mathrm{m}$. \\
\hline Bathing with boiled leaf extract & & $\mathrm{X}$ & $\mathrm{X}$ & $\mathrm{X}$ & $\mathrm{X}$ & $\mathrm{X}$ \\
\hline Dried leaf powder & & $\mathrm{X}$ & $\mathrm{X}$ & $\mathrm{X}$ & $\mathrm{X}$ & $\mathrm{X}$ \\
\hline Bathing with boiled bark extract & $\mathrm{X}$ & & & & & \\
\hline Dried bark powder & $\mathrm{X}$ & & & & & \\
\hline Poultice of raw leaves & & & $\mathrm{X}$ & & $\mathrm{X}$ & \\
\hline Poultice of leaf extract & & & $\mathrm{x}$ & & & \\
\hline Paste of fresh leaves & & & $\mathrm{X}$ & & $X$ & \\
\hline
\end{tabular}
americanum; P. m. = Plantago major.

Schott), malva-branca (Sida cordifolia L.) and pau d'arco (Tabebuia cf. umbellata (Sond.) Sandw.) were cited by $10 \%$ and in Corte de Pedra pinhão-roxo (Jatropba gossypfolia L.), pequi (Caryocar edule Casar) and fumo (Nicotiana tabacum L.).

Sometimes more than one species was used in same application. Local methods of application are detailed in Table 2 . Systemic treatment was not noted.

\section{DISCUSSION}

If a plant could be found with therapeutic activity against Lvb it would be useful as current therapy is unsatisfactory ${ }^{1}$. Even if it had only local activity it would be of value since there is evidence that the incidence of mucosal metastatic spread is low ${ }^{15}$.
In Três Braços there was less herbal use than in Corte de Pedra, which is not suprising in view of the existence of a health post in this village since 1974 . Comparing the two villages we noted that $36 \%$ of the plants were used at both sites. In Corte de Pedra a wider spectrum was noted although in $56 \%$ of instances a single individual recommended the plant. Only $36 \%$ of isolated citations occurred in Três Braços where there was more of a consensus. Nation wide the number of such remedies must be large indeed.

Since the Três Braços community is more isolated $32 \%$ of people using plants did not seek professional help, but in Corte de Pedra where the health post function daily this number falls to $7 \%$. However $45 \%$ of patients attending the latter post used plants as 
França F, Lago EL, Marsden PD. Plants used in the treatment of leishmanial ulcers due to Leishmania (Viannia) Braziliensis in an endemic area of Babia, Brazil. Revista da Sociedade Brasileira de Medicina Tropical 29:229-232, mai-jun, 1996.

additional treatment compared with $12 \%$ in Três Braços.

Interview data revealed that the longer the duration of the lesion the greater the use of plants. The same applied when lesions were multiple and widely distributed on the body. As shown previously more men that women acquire the disease ${ }^{7}$. Often up to three species were used in topical treatment. When subjects changes of treatment occurred, the apparent response was not good.

Only six plants were recommended by more than $20 \%$ of interviewed for local treatment. Of the plants mentioned in this paper only Anacardium occidentale L. and Chenopodium ambrosioides L. have been cited for use against leishmaniasis in the area ${ }^{16}$. Plantago major $\mathrm{L}$. is a species much studied in Russia and Japan and used as an astringent, antipyretic etc ${ }^{11}$ and for haemorrhoids ${ }^{2}$. Solanum americanum Mill. is used in diverse dermatoses such as eczema, psoriasis and skin trauma or infections ${ }^{1 i}$. Clidemia birta L. was the plant preferred after cajueiro. Their fruits are edible and rich in vitamin $\mathrm{C}^{2}$. Cbenopodium ambrosioides $\mathrm{L}$. is a known anthelminthic very effective against ascariasis due to its high content of ascaridol ${ }^{11}$. It is also used as an abortificant and for digestive effects ${ }^{2}$.

Anacardium occidentale L. nut extract was the most widely used. It contains corrosive substances and has been used in other diseases such as leprosy, psoriasis, eczema and warts ${ }^{2} 813$. Other parts of the plant have medicinal uses ${ }^{12}$.

Elsewhere we presented our results of testing extracts of Anacardium occidentale L. bark in laboratory experiments with Lvb in vivo ${ }^{4}$. This extract showed high activity in the in vitro model against promastigote of this species. However in the in vivo model no curative activity was observed in the hamster.

\section{RESUMO}

Este trabalbo relata as plantas usadas no tratamento da leishmaniose cutânea, causada por Leishmania (Viannia) braziliensis $(L(V) b), n a$ população rural da faixa litorânea produtora de cacau do estado da Babia, Brasil. Um inquérito realizado entre 100 pacientes, identificou 49 espécies de plantas usadas para tratar úlceras de pele causadas por esta espécie de Leishmânia. As principais plantas usadas foram o cajueiro-branco
(Anacardium occidentale - Anacardiaceae) usado por $65 \%$ da população, a folba-fogo (Clidemia hirta - Melastomataceae) 39\%, a alfavaca-grossa (Plectranthus amboinicus - Lamiaceae) 33\%, o mastruz (Chenopodium ambrosioides benopodiaceae) 31\%, a erva-de-santa-maria (Solanum americanum - Solanaceae) 25\% e a transagem (Plantago major - Plantaginaceae) 2\%.

Palavras-cbaves: Leisbmaniose cutânea. Leishmania (Viannia) braziliensis. Tratamento com plantas

\section{REFERENCES}

1. Berman JD. Chemotherapy for leishmaniasis, biochemical mecanisms, clinical efficacy and future strategies. Reviews of Infectious Diseases 10: $560-586,1980$.

2. Correa PM. Diccionário das plantas úteis e das exóticas cultivadas. Ministério da Agricultura/ IBGE ( 6 vol.). Rio de Janeiro. 1929.

3. De Smet PAGM, Rivier L. A general outlook on ethnopharmacology. Journal of Ethnopharmacology 25: 127-138, 1989.

4. França F, Cuba CAC, Moreira EA, Miguel O, Almeida MD, Virgens ML, Marsden PD. Avaliação do efeito do extrato de casca de cajueiro-branco (Anacardium occidentale L.) sobre a infecção por Leisbmania (Viannia) braziliensis. Revista da Sociedade Brasileira de Medicina Tropical 26: 151-155, 1993.

5. França F, Lago EL, Tada MS, Costa JML, Vale K, Oliveira J, Costa MA, Osaki N, Cheever L, Netto EM, Barreto AC, Johnson WD, Marsden PD. An outbreak of human Leisbmania (Viannia) braziliensis (LVb). Memórias do Instituto Oswaldo Cruz 86: 169-174, 1991.

6. Friedman J, Yaniv Z, Dafni A, Palewitch D. A preliminary classification of the healing potential of medicinal plants, based on a rational analysis of an ethnopharmacological field survey among bedouin in the negev Desert, Israel. Journal of Ethnopharmacology 16:275- 287, 1986.

7. Jones TC, Johnson Jr WD, Barreto AC, Lago E, Badaró R, Cerf B, Reed SG, Netto EM, Tada MS, França F, Wiese K, Golightly L, Fikrig E, Costa JML, Cuba CC, Marsden PD. Epidemiology of american cutaneous leishmaniasis due to Leishmania (Viannia) braziliensis. The Journal of Infectious Diseases 156: 73-83, 1987.

8. Léon J. Botánica de los cultivos tropicales. IICA, San José, 1987. 
França F, Lago EL, Marsden PD. Plants used in the treatment of leishmanial ulcers due to Leishmania (Viannia) Braziliensis in an endemic area of Babia, Brazil. Revista da Sociedade Brasileira de Medicina Tropical 29:229-232, mai-jun, 1996.

9. Macêdo FEA. Proposta alternativa de terapia para leishmaniose tegumentar americana. Universidade Federal da Paraíba. Mimeographed document, João Pessoa, 1986.

10. Mello MOA, Costa CF, Barbosa MS, Oliveira EL. Catálogo de plantas medicinais do Estado da Bahia. Boletim do Instituto Biológico da Bahia 10: 39-66, 1971.

11. Menezes AI. Flora da Bahia. Companhia Editora Nacional, São Paulo, 1949.

12. Mitchell DJ, Mori SA.The cashew and its relatives (Anacardium: Anacardiaceae). Memoirs of the New York Botanical Garden 42: 1-76, 1987.

13. Morais MO. O óleo de caju na lepra. Revista Brasileira de Farmácia 26: 17-20, 1945.

14. Nawwar MAM. Quercetin 3-glycosides from the leaves of Solanum nigrum. Phytochemistry 28: 1755-1758, 1989.

15. Netto EM, Marsden PD, Llaños-Cuentas EA, Costa JM, Cuba CC, Barreto AC, Badaró R, Johnson WD,
Jones TC. Long term follow up of patients with Leishmania (Viannia) braziliensis infection and treated with glucantime. Transactions of Royal Society of Tropical Medicine and Hygiene 84: 367370,1990

16. Netto EM,Tada MS, Golightly L, Kalter DC, Lago E, Barreto AC, Marsden PD. Conceitos de uma população local a respeito da leishmaniose mucocutânea em uma área endêmica. Revista Brasileira de Medicina tropical 18: 33-37, 1985.

17. Rizzini CT. Coleta e preparo de material vegetal para estudos químicos e farmacológicos.Arquivos do Jardim Botânico do Rio de Janeiro 30: 179-190, 1981.

18. Rosa AC, Cuba CC, Vexenat A, Barreto AC, Marsden PD. Predominance of Leishmania braziliensis braziliensis in the regions of Três Braços and Corte de Pedra, Bahia, Brazil. Transactions of the Royal Society of Tropical Medicine and Hygiene 82: 409-410, 1988. 